\title{
Review of the Anti-Corruption Components of Ministerial 100-Day Plans
}

\section{Introduction}

Earlier this year, President Ashraf Ghani instructed all ministries and independent budgetary departments to prepare "100-Day Plans" (hereinafter the "Plan(s)") describing how they intended to improve provision of services to the people and implement internal reforms to improve the efficiency of their operations. All 25 ministries were required to submit 100-Day Plans, as were several other independent agencies. However, notwithstanding repeated written and verbal requests, MEC did not receive Plans from all of these institutions. As of mid-August, 18 ministries and four other agencies provided MEC with their Plans. In justifying their lack of response to MEC's request, several nonministerial agencies responded that they only briefed the President orally on their Plans and had nothing memorialized in writing. Of the Plans received by MEC, many were short (e.g., the Ministry of Women's Affairs (MOWA) presented a 2-page Plan), with the longest being the 24-page document produced by the Ministry of Counter-Narcotics. With regard to addressing corruption issues, only six of the 22 Plans analyzed by MEC contain a specific anti-corruption section, but most of the other Plans include procedural reforms that, if implemented, could reduce corruption. Although the 100-day benchmark is arbitrary in nature and not a particularly useful metric to evaluate policies that may take years to bear

fruit, the drafting of such Plans provides a useful, if limited, view of a ministry's priorities over the short term.

\section{Institutions that provided MEC with a copy of their 100-Day Plan}

Not surprisingly, the content of most Plans focused on the ministries' core activities, with reducing corruption addressed as an ancillary matter, either in a brief sub-section or as an expected outcome of other institutional reforms. While none of the Plans explicitly incorporate MEC's recommendations, many Plans contained proposed operational changes that are in line with reforms advocated by MEC. The following Afghan government agencies provided MEC with a copy of their Plans:

- Ministry of Labor, Social Affairs, Martyrs, and Disabled

- Ministry of Justice

- Ministry of Public Health

- Ministry of Parliamentary Affairs

- Ministry of Refugees and Repatriations

- Ministry of Urban Development Affairs

- Ministry of Finance

- Ministry of Education 
- Ministry of Border and Tribal Affairs

- Central Statistics Organization

- Da Afghanistan Bank

- Ministry of Communications and Information Technology

- Ministry of Foreign Affairs

- Ministry of Information and Culture

- Ministry of Counter-Narcotics

- Ministry of Public Works

- Ministry of Women's Affairs

- Supreme Audit Office

- Ministry of Rural Rehabilitation and Development

- Ministry of Energy and Water

- Ministry of Mines and Petroleum

- Independent Administrative Reform and Civil Service Commission

Notably absent from the list of respondents are the Ministries of Interior and Defense, as well as the Independent Directorate of Local Governance.

\section{The oversight role of the Office of Administrative Affairs}

All ministries and agencies with a 100-Day Plan are required to update the status of their implementation every 25 days to the Administrative Office of the President (AOP). The AOP is also currently developing a standardized format for institutions to use when submitting future Plans. Currently, it is anticipated that ministries and agencies will be required to submit at least three more 100-Day Plans.

\section{0-Day Plans with Significant Anti-Corruption Features}

The Plans of the Ministries of Public Health; Parliamentary Affairs; Justice; Refugees and Repatriations; Labor, Social Affairs, Martyrs, and the Disabled; and Urban Development Affairs all contained subsections focusing on anti-corruption plans and policies. Most other ministries, however, indirectly addressed the issue of corruption. For example, the Ministry of Economy's Plan contained a section describing a comprehensive review that it plans to conduct on the waste, fraud, and abuse of foreign- 
assistance expenditures. For the aforementioned six institutions whose Plans contain anti-corruption sections, details were sometimes lacking. In their stead were broad assurances about a variety of issues relating, sometimes only tenuously, to combating corruption. Oft-mentioned anti-corruption policies included in these Plans include building the capacity of human-resource management, simplifying working processes, creating a monitoring and evaluation system, and conducting a review of internal procedures.

\section{Ministry of Labor, Social Affairs, Martyrs, and the Disabled (MOLSAMD)}

A significant part of MOLSAMD's strategic objectives in its first 100-day Plan is "to fight against [the] causes of corruption." The Ministry stated that it planned to conduct an assessment of its vulnerability to administrative corruption through questionnaires and interviews that would be concluded by midAugust. Further, MOLSAMD's Plan mentions the Minister's intention to establish an internal anticorruption board staffed by permanent Ministry employees with specific job descriptions. MOLSAMD's Plan also identified the complicated and lengthy procurement process as a corruption vulnerability, stating that the Ministry would be drafting a Plan to simplify those processes. Overall, MOLSAMD's Plan provided more details on anti-corruption initiatives than most other ministries, with clear objectives linked to defined timeframes.

\section{Ministry of Justice (MOJ)}

Under the "Fight against Corruption" section in its Plan, the MOJ mentions several anti-corruption measures, but provides scant details about how it would implement them. Among the objectives included in MOJ's Plan are effectively addressing citizens' legal petitions, reviewing the performance of Kabul-based and provincial departments, and creating a regular reporting database for the first time in Balkh and Herat provinces. MOJ's plan also features a proposal to analyze how seven departments performed during 2014. Additionally, MOJ is planning to develop its internal audit procedures to enhance the transparency of its operations. However, the Plan is lacking in details and realistic timeframes and cannot be considered a plausible path to reform for this troubled Ministry.

\section{Ministry of Public Health (MOPH)}

The "Fight against Corruption" section of MOPH's Plan includes a rudimentary overview of the current corruption problems within the Ministry. The Plan also emphasizes a renewed effort to monitor and assess the performance of MOPH facilities located outside of Kabul. The remainder of this relatively short section lists simplifying procurement, setting up a system for receiving complaints, developing a strategy for the prevention of corruption, and enhancing the capacity of the its internal inspections office.

\section{Ministry of Parliamentary Affairs}

The "Prevention of Corruption" section it its Plan stresses that all Ministry transactions closely follow the Procurement Law and associated regulations. The Ministry's Plan also proposes establishing an internal 
complaint-review body to evaluate claims of employee misconduct and states that the Ministry will endeavor to increase its cooperation with other ministries with regard to accelerating the passage of long-stalled legislation. Additionally, the Plan acknowledges that current hiring practices are flawed and lists a move toward a merit-based hiring policy as one of its primary goals. As a long-term objective, the Ministry intends to conduct an agency-wide review of its structure and policies as part of a gradual restructuring process designed to increase its operational effectiveness.

\section{Ministry of Refugees and Repatriations (MORR)}

The MORR's "practical plan for combating corruption" proposes establishing a special committee that would be charged with implementing unspecified anti-corruption measures. However, the Plan does not provide information about how the proposed committee would fit within the MORR's structure, nor does it detail the committee's duties, responsibilities, or authorities.

\section{Ministry of Urban Development Affairs}

This Ministry's Plan contains a "Fight against Corruption" section that proposes a review of all contracts entered into by the Ministry in the past and, ultimately, the creation of a transparent contracting mechanism. This review would be part of a holistic assessment of all ministry operations designed to eliminate inefficiencies and corruption. Further, the Plan states that the Ministry will take steps to ensure all personnel have accurate job descriptions and that departments do not have overlapping or redundant mandates. The Plan also stresses the need to reform the existing procedures regulating the provision of housing so as to lessen the influence of politically connected individuals and make the process more transparent. Other initiatives described in the Plan include: eliminating overlapping responsibilities that often bring the Ministry into conflict with municipal governments, streamlining administrative procedures, reorganizing the human-resources department, and building the capacity of its provincial staff through additional training.

\section{Ministry of Finance}

Although this Plan does not group the discussion of its anti-corruption policies in one particular subsection, it is still one of the most detailed and comprehensive Plans provided to MEC. The Plan emphasizes increased coordination with the donor community to meet the objectives set forth during the 2014 London Conference. To accomplish this, the Ministry proposes a revised donor-assistance database, as well as a revised aid-management policy. The Plan also stresses the importance of robust monitoring and evaluation mechanisms to guard against the waste of public funds. These monitoring efforts would be focused on 14 budgetary entities and about 60 development projects now underway. In addition, the Ministry plans to examine the balance sheets and bank accounts of more than 20 stateowned enterprises and assess the strategic plans of several others. With regard to legal reform, the Plan prioritizes the passage of the Accounting and Audit Law and amendments to the Income Tax Law. It also cites the need for improving the exchange of customs information with other countries, such as Tajikistan, to increase revenue and reduce corruption. To achieve this, the Ministry proposes, inter alia, 
establishing a National Academy of Customs to improve the quality of personnel manning border posts and other customs offices.

\section{Ministry of Education}

To reduce corruption and increase its overall effectiveness, the Ministry proposes reviewing all procurement procedures to identify corruption risks and find solutions for them, assigning Ministry staff to examine complaints lodged by many teachers about delays in salary payments, and gradually implementing a biometric system to track salary payments. These and other reforms would be part of a comprehensive strategic plan that the Ministry hopes to draft.

\section{Ministry of Border and Tribal Affairs}

The Ministry's Plan places a significant emphasis on improving its ability to monitor projects underway outside of Kabul so as to identify any problems at an early stage and implement the necessary corrective actions. The Plan also proposes updating the Ministry's financial-management systems and reforming its procurement procedures. Notably, the Plan singles out several provinces where Ministry activities are in need of enhanced oversight, including Helmand, Kandahar, Panjshir, Parwan, Wardak, Balkh, Samangan, and Baghlan.

\section{Other ministries and agencies}

The institutions discussed above produced Plans containing reasonably specific anti-corruption proposals. The Plans of other ministries and agencies were somewhat less specific, though the reforms contained in these Plans-if implemented-also have the potential to reduce corruption and administrative inefficiencies. Examples of such Plans are listed in the chart below.

\begin{tabular}{|c|c|}
\hline Ministry or other Government Agency & Anti-Corruption Elements of 100-Day Plan \\
\hline Central Statistics Organization & $\begin{array}{l}\text { - Develop electronic data-collection system } \\
\text { - } \quad \text { Revise data-collection forms and procedures }\end{array}$ \\
\hline Da Afghanistan Bank & $\begin{array}{l}\text { - Increase oversight of all banks } \\
\text { - Amend the Regulation on Foreign Exchange } \\
\text { Dealers, based on the articles of the Da } \\
\text { Afghanistan Bank Law } \\
\text { - Produce guidelines for the oversight of non- } \\
\text { banking organizations involved in matters } \\
\text { pertaining to anti-money-laundering activities } \\
\text { and tracking terrorist financing }\end{array}$ \\
\hline
\end{tabular}




\begin{tabular}{|c|c|}
\hline $\begin{array}{l}\text { Ministry of Communications and } \\
\text { Information Technology }\end{array}$ & - Revise internal training system and curriculum \\
\hline Ministry of Foreign Affairs & $\begin{array}{l}\text { - Establish an e-mail complaint system } \\
\text { - Reform hiring practices to reduce nepotism and } \\
\text { favoritism }\end{array}$ \\
\hline Ministry of Information and Culture & $\begin{array}{l}\text { - Set up a policy-development committee to assess } \\
\text { proposed reforms }\end{array}$ \\
\hline Ministry of Counter-Narcotics & $\begin{array}{l}\text { - Create a new monitoring and evaluation } \\
\text { mechanism to oversee and report on Ministry } \\
\text { activities }\end{array}$ \\
\hline Ministry of Public Works & $\begin{array}{l}\text { - Transition to an electronic information- } \\
\text { management system } \\
\text { - Conduct a detailed assessment of six significant } \\
\text { projects that are either behind schedule or } \\
\text { completely stalled }\end{array}$ \\
\hline Ministry of Women's Affairs & $\begin{array}{l}\text { Review all internal regulations and position } \\
\text { descriptions to reduce bureaucratic complexity } \\
\text { and inefficiency } \\
\text { - Reform hiring process } \\
\text { - Review internal operating structure of the } \\
\text { Ministry and possibly reorganize it }\end{array}$ \\
\hline Supreme Audit Office & $\begin{array}{l}\text { - Reform the process by which audit results are } \\
\text { communicated to the Attorney General's Office }\end{array}$ \\
\hline $\begin{array}{l}\text { Ministry of Rural Rehabilitation and } \\
\text { Development }\end{array}$ & $\begin{array}{l}\text { - Conduct a comprehensive assessment of Ministry } \\
\text { operations to identify gaps and deficiencies }\end{array}$ \\
\hline Ministry of Energy and Water & $\begin{array}{l}\text { - Enhance inspection capacity to enable increased } \\
\text { monitoring of ongoing projects } \\
\text { - Prepare a list of corruption vulnerabilities and } \\
\text { propose legal and policy changes aimed at } \\
\text { reducing them }\end{array}$ \\
\hline
\end{tabular}




\begin{tabular}{|l|l|}
\hline Ministry of Mines and Petroleum & $\begin{array}{l}\text { Create an effective financial-reporting system } \\
\text { capable of tracking revenue collection and } \\
\text { expenditures }\end{array}$ \\
& $\begin{array}{l}\text { - Identify illegal mining operations } \\
\text { - }\end{array}$ \\
\hline $\begin{array}{l}\text { Independent Administrative Reform and } \\
\text { Civil Service Commission }\end{array}$ & $\begin{array}{l}\text { Complete the process of amending the Minerals } \\
\text { in the appointment and hiring process }\end{array}$ \\
\hline
\end{tabular}

\section{Common shortcomings}

After reviewing the 22 Plans provided to MEC, several common deficiencies were readily apparent:

- a failure to outline implementation mechanisms necessary for achieving the desired goals;

- insufficient detail about most initiatives described in the Plans;

- a general lack of prioritization;

- unclear relationship between the Plans and the ministries' current resources and future budgets;

- the lack of monitoring and evaluation to track the progress of the Plans;

- unrealistic, short-term goals and overly ambitious timeframes; and

- a failure to directly address MEC's recommendations.

While these flaws by no means affected all Plans, they were common enough to warrant attention. 


\section{Recommendations}

\begin{tabular}{|c|c|c|c|c|c|}
\hline OUTCOME & INDICATOR & TARGET & & BASELINE & STATUS \\
\hline \multirow{3}{*}{$\begin{array}{l}\text { Inclusion of anti- } \\
\text { corruption } \\
\text { measures in all } \\
\text { future 100-Day } \\
\text { Plans. }\end{array}$} & \multirow{2}{*}{$\begin{array}{l}\text { 1. Anti- } \\
\text { corruption } \\
\text { measures } \\
\text { should be } \\
\text { included in } \\
\text { the } 100-\text { Day } \\
\text { Plans. }\end{array}$} & 1.1 & $\begin{array}{l}\text { A specific section } \\
\text { addressing anti- } \\
\text { corruption } \\
\text { initiatives exists in } \\
\text { all future 100-Day } \\
\text { Plans. }\end{array}$ & $\begin{array}{l}\text { (15 Aug. 2015) } \\
\text { Only six } \\
\text { ministries } \\
\text { explicitly } \\
\text { include anti- } \\
\text { corruption } \\
\text { sections in } \\
\text { their 100-Day } \\
\text { Plans. }\end{array}$ & \\
\hline & & 2.1 & $\begin{array}{l}\text { Anti-corruption } \\
\text { measures are } \\
\text { effectively } \\
\text { monitored by the } \\
\text { AOP. }\end{array}$ & $\begin{array}{l}\text { (15 August } \\
2015) \\
\text { The AOP is in } \\
\text { the process of } \\
\text { reviewing the } \\
\text { first set of } \\
\text { 100-Day Plans. }\end{array}$ & \\
\hline & $\begin{array}{l}\text { 2. Timely } \\
\text { public } \\
\text { access to all } \\
\text { 100-Day } \\
\text { Plans. }\end{array}$ & 1.2 & $\begin{array}{l}\text { Online publication } \\
\text { of all } 100 \text {-Day Plans } \\
\text { on the official } \\
\text { website of relevant } \\
\text { ministries and } \\
\text { agencies. }\end{array}$ & $\begin{array}{l}\text { (15 Aug. 2015) } \\
\text { Several } \\
\text { agencies only } \\
\text { provided oral } \\
\text { summaries of } \\
\text { their Plans to } \\
\text { the President } \\
\text { and did not } \\
\text { publish them. }\end{array}$ & \\
\hline
\end{tabular}

